\title{
Yersinia enterocolitica causing suppurative arthritis of the shoulder
}

\author{
F Tiddia, G B Cherchi, L Pacifico, C Chiesa
}

\begin{abstract}
Yersinia enterocolitica is a rare cause of extra-intestinal disease. A case in a 60 year old butcher with hepatic cirrhosis who developed suppurative arthritis of the shoulder caused by $Y$ enterocolitica is presented. There was no evidence of gastrointestinal infection or septicaemia. The severity of the illness was associated with various factors, including the underlying disease, the type of occupation, and the difficulties encountered in defining the optimal therapeutic regimen.
\end{abstract}

(F Clin Pathol 1994;47:760-761)

Yersinia enterocolitica, an aerobic Gram negative organism, is a well recognised cause of diarrhoeal disease. It rarely causes systemic infection, particularly in compromised hosts. While althralgia and the non-septic rheumatic type of arthritis have frequently been associated with $Y$ enterocolitica infection, septic arthritis with isolation of the organism from the synovial fluid is rare, with only nine cases reported so far. ${ }^{1-8}$

We describe the tenth case of suppurative arthritis caused by $Y$ enterocolitica and the fourth case to present with disease in the shoulder, documented by synovial fluid culture and serological studies.

\section{Case report}

A 60 year old butcher who had hepatic cirrhosis was admitted to hospital with a 10 day history of severe pain in his left shoulder and fever of one day's duration. He received a course of non-steroidal antiinflammatory agents without improvement. There was no history of shoulder trauma, abdominal pain, diarrhoea or recent travel.

On admission, his temperature was $39.5^{\circ} \mathrm{C}$, blood pressure $140 / 80 \mathrm{~mm} \mathrm{Hg}$, and his pulse 98 per minute. The left shoulder showed no signs of inflammation, but the range of motion was extremely limited due to severe pain. The initial laboratory data included the following: erythrocyte sedimentation rate 70 $\mathrm{mm} /$ first hour, white cells $19.8 \times 10^{9} / 1$, with $91 \%$ polymorphonuclear cells, a haemoglobin concentration of $150 \mathrm{~g} / 1$, haematocrit of $43 \%$, and a platelet count $134 \times 10^{9} / 1$. X ray pictures of the chest and the left shoulder showed no abnormalities. Blood, stool, and urine cultures were obtained and empiric treatment with intravenous cefotaxime ( $3 \mathrm{~g} /$ day) was begun.

Over the next 10 days his temperature gradually fell to normal, but shoulder pain persisted. On the 11th day swelling, warmth, and tenderness were noted over the left shoulder. Aspiration of the affected joint yielded 35 $\mathrm{ml}$ of purulent bloody material and Gram negative bacilli were observed on smears. Cultures from the aspirate grew $Y$ enterocolit ica biogroup 4, serogroup 03, phage type VIII, while blood, urine, and stool cultures were reported to be negative.

The organism was susceptible to cefotaxime, ceftazidime, gentamicin, netilmicin norfloxacin, chloramphenicol, and amoxicillin/clavulanate according to the KirbyBauer disk method. It was also resistant to ampicillin and cephalothin. Given the susceptibility testing of the isolate, cefotaxime was continued. The patient continued to remain afebrile. On the 16th hospital day, his temperature rose again to $39.5^{\circ} \mathrm{C}$. A second joint puncture was performed and the aspirated material grew $Y$ enterocolitica biogroup 4 serogroup 03, phage type VIII in pure culture. Cefotaxime was then substituted for intravenous netilmicin ( $200 \mathrm{mg} /$ day).

Treatment was continued for three weeks with gradual improvement of the patient's clinical condition. On follow up the patient had no signs of permanent injury to the shoulder.

Serological testing was a diagnostic adjunct for evidence of acute infection with $Y$ enterocolitica. The patient's serum reacted with his own isolate to reach a very high agglutination titre $(1 / 2,048)$ on day 16 of illness and fell to $(1 / 256)$ one month after completion of netilmicin treatment.

\section{Discussion}

The signs and symptoms of yersiniosis are variable, depending on the age and immunocompetence of the host. Infants and children characteristically present with fever, diarrhoea, and vomiting, whereas mesenteric adenitis and acute terminal ileitis are most typical in adolescents and young adults. Common postinfectious signs in adults include reactive arthritis, erythema nodosum, and Reiter's syndrome. Septicaemia due to $Y$ enterocolitica is very rare and generally associated with infancy, advanced age, or an underlying debilitating illness-specifically diabetes, hepatic cirrhosis, and blood dyscrasias. In these patients suppurative lesions may occur in 
Summary of documented cases of septic arthritis caused by Yersinia enterocolitica

\begin{tabular}{|c|c|c|c|c|c|c|}
\hline $\begin{array}{l}\text { Case } \\
\text { No }\end{array}$ & Reference & $\begin{array}{l}\text { Sex/age } \\
\text { (years) }\end{array}$ & Predisposition & Site of isolation & Treatment & Outcome \\
\hline 1 & 1 & $F / 6,5$ & Thalassemia & $\begin{array}{l}\text { Blood; } \\
\text { right hip }\end{array}$ & $\begin{array}{l}\text { Ampicillin, Kanamycin, } \\
\text { Chloramphenicol, } \\
\text { Streptomycin }\end{array}$ & Recovered \\
\hline 2 & 2 & M/75 & & $\begin{array}{c}\text { Blood; right } \\
\text { shoulder }\end{array}$ & Chloramphenicol, Ampicillin & Recovered \\
\hline $\begin{array}{l}3 \\
4\end{array}$ & $\begin{array}{l}3 \\
4\end{array}$ & $\begin{array}{l}\mathrm{F} / 39 \\
\mathrm{M} / 69\end{array}$ & $\begin{array}{l}\text { Cirrhosis } \\
\text { Lymphoma }\end{array}$ & $\begin{array}{l}\text { Blood; right hip } \\
\text { Blood; right } \\
\text { shoulder }\end{array}$ & $\begin{array}{l}\text { Chloramphenicol } \\
\text { Gentamicin, Chloramphenicol }\end{array}$ & $\begin{array}{l}\text { Died } \\
\text { Recovered }\end{array}$ \\
\hline 5 & 5 & $\mathrm{M} / 58$ & & $\begin{array}{l}\text { Blood, sputum; } \\
\text { left wrist }\end{array}$ & $\begin{array}{l}\text { Cephalotin, Clindamycin, } \\
\text { Gentamicin, Tetracycline, } \\
\text { Chloramphenicol }\end{array}$ & Recovered \\
\hline $\begin{array}{l}6 \\
7 \\
8 \\
9 \\
10\end{array}$ & $\begin{array}{l}6 \\
6 \\
7 \\
8 \\
\text { This report }\end{array}$ & $\begin{array}{l}M / 55 \\
F / 35 \\
F / 56 \\
F / 84 \\
M / 60\end{array}$ & $\begin{array}{l}\text { Cirrhosis } \\
\text { Lupus cutaneous } \\
\text { Right knee arthroplasty } \\
\text { Cirrhosis }\end{array}$ & $\begin{array}{l}\text { Right knee } \\
\text { Right knee } \\
\text { Right shoulder } \\
\text { Right knee } \\
\text { Right shoulder }\end{array}$ & $\begin{array}{l}\text { Streptomycin } \\
\text { Chloramphenicol, Doxycicline } \\
\text { Rifampin, Doxycicline } \\
\text { Cefuroxime } \\
\text { Cefotaxime, Netilmicin }\end{array}$ & $\begin{array}{l}\text { Recovered } \\
\text { Recovered } \\
\text { Recovered } \\
\text { Recovered } \\
\text { Recovered }\end{array}$ \\
\hline
\end{tabular}

various organ systems, such as lung, liver, joint.

In the previously reported nine cases of $Y$ enterocolitica septic arthritis (table) a higher incidence of the disease was seen over the fifth decade of life. Most of these patients had underlying illnesses. Sites of infection included the shoulder, knee, wrist, and hip. Four cases, including ours, involved the shoulder, a distinctly unusual site for bacterial arthritis. Other features included a history of gastrointestinal complaints such as diarrhoea in only two of the 9 reported subjects, presence of septicaemia in four of them, and a satisfactory outcome following antibiotic treatment in all but one patient.

$Y$ enterocolitica has been isolated from soil, water, wild and domestic animals, and animal products. In Europe pigs constitute an important reservoir for pathogenic strains of $Y$ enterocolitica, including those belonging to biogroup 4, serogroup 03, phage type VIII. Such strains have been isolated from the tongue, throat, tonsils, caecal contents, and faeces of pigs, as well as from pork, ham, and butcher-shop cutting boards. There is, in fact, an unequivocal increased risk of Yersinia infections among abattoir workers. ${ }^{9}$

In people the most common portal of entry is the gastrointestinal tract by ingestion of contaminated food, water, and milk. The oral-oral and faecal-oral routes have been implicated in reports of transmission from dogs, cats, and pigs to people. Person-to-person transmission has been convincingly documented by the transfusion of blood products.

How our patient contracted the infection is unknown. He denied any history of shoulder trauma or transfusion of blood products. On admission he lacked clinical and bacteriological evidence of gastrointestinal infection and bacteraemia. We speculate that the patient's underlying disease and occupation, entailing direct contact with pork products, predisposed to occult bacteraemia with subsequent joint infection after subclinical enteritis.

There is no well established antibiotic regimen for the treatment of serious $Y$ enterocolitica infections. In vitro studies show susceptibility to aminoglycosides, tetracycline, chloramphenicol, trimethoprim/sulfamethoxazole, newer $\beta$ lactam drugs (third generation cephalosporins, aztreonam, imipenem), and fluoroquinolones, and resistance to older $\beta$ lactam agents (benzylpenicillin, aminopenicillins, first generation cephalosporins), regardless of the phenotype or geographical origin of $Y$ enterocolitica strains. The use of third generation cephalosporins for the treatment of patients with serious conditions due to $Y$ enterocolitica has been reported in individual cases. Most often, the clinical response has been favourable, though some failures have been recently described. Scavizzi and coworkers evaluated the in vivo activity of cefotaxime, imipenem, gentamicin and doxycycline against the virulent serogroup $08 Y$ enterocolitica in a mouse model of systemic infection and found that the two $\beta$ lactam antibiotics, active in vitro, were inferior to gentamicin and doxycycline in controlling the infection. ${ }^{10}$

Our patient, who failed to respond clinically and bacteriologically to cefotaxime, despite the susceptibility of the isolate in vitro, was successfully treated with netilmicin, suggesting a clinical use for aminoglycosides in the treatment of septic arthritis due to $Y$ enterocolitica.

This work was supported in part from Consiglio Nazionale delle Ricerche (Progetto Finalizzato FATMA, grant No 93.04983 PF41).

1 Blum D, Viart P, Dachy A. Septicémie à Yersinia enterocolitica chez deux enfants atteints de thalassemie majeure. Arch Fr Pediatr 1970;27:445.

2 Keet EE. Yersinia enterocolitica septicemia. NY State $\mathcal{f}$ Med 1974;74:2226-30.

3 Sirot J, Morin B, Briat JP, Lopitaux R, Delage J, Ricoux $M$, Chanal $M$. Deux cas de suppuration profonde à Yersinia enterocolitica. Méd Mal Infect 1976;6:329-34.

4 Spira TJ, Kabins SA. Yersinia enterocolitica septicemia with septic arthritis. Arch Intern Med 1976;136:1305-8.

5 Taylor BG, Zahir Zafarzai M, Humphreys DW, Manfredi F. Nodular pulmonary infiltrates and septic arthritis associated with Yersinia enterocolitica bacteremia. Am Rev Resp Dis 1977;116:525-9.

6 Ziegler G, Euller L, Dellamonica P, Etesse H. Deux cas d'arthrite à Yersinia enterocolitica avec mise en évidence
du germe intra-articulaire. Rev Rheum 1981;48:118-20.

7 Treves R, Jacob P, Arnaud M, Papapietro PM, Tricard MJ, Morvan C, et al. Arthrite à Yersinia enterocolitica MJ, Morvan C, et al. Arthrite à Yersinia enterocolitica
avec présence de germe intra-articulaire. Rev Rheum avec présence

8 Oni JA, Kangesu T. Yersinia enterocolitica infection of a prosthetic knee joint. Br f Clin Pract 1991;45:225.

Seuri $M$. Risk of appendicectomy in occupations entailing contact with pigs. BMF 1991;303:345-6.

10 Scavizzi MR, Alonso J-M, Philippon AM, Jupeau-vessieres AM, Guiyoule A. Failure of newer beta-lactam antibiotics for murine Yersinia enterocolitica infection. Antimicrob Agents Chemother 1987;31:523-6. 